\title{
PENGEMBANGAN MEDIA TOUCH AND PLAY 3D IMAGES MATERI PANCA INDERA KELAS IV SEKOLAH DASAR BERBASIS ADOBE FLASH
}

\author{
Ilmiah Nu Izzah ${ }^{1)}$, Dyah Worowirastri Ekowati ${ }^{1)}$, Husamah ${ }^{2)}$ \\ 1) Pendidikan Guru Sekolah Dasar FKIP Universitas Muhammadiyah Malang \\ 2) Pendidikan Biologi FKIP Universitas Muhammadiyah Malang \\ Email : ${ }^{1)}$ usyabio@yahoo.com \\ 1)dyah_umm@yahoo.com \\ ${ }^{2}$ husamahumm@gmail.com
}

Naskah diterima 15 Juli 2017 disetujui 30 Agustus 2017

\begin{abstract}
The use of teaching media in the 4th Grade of SDN Sukorejo IV, Sukerejo District, Pasuruan Regency has not been maximal, thus resulting the decreasing level of students' motivation during the learning session. Then, it is needed an effort to escalate the students' motivation in learning through the development and utilization of learning media. This research is conducted to produce The development of Touch and Play 3D Images Learning Media Based on Adobe Flash in the Five Senses Subject at 4th Grade of Elementary School, and to describes The students' responses in the implementation of touch and play 3D images learning media based on Adobe Flash in the Five Senses Subject at 4th Grade of Elementary School. The research show that: The development of Touch and Play 3D Images learning media based on Adobe Flash in the Five Senses Subject at 4th Grade of Elementary School using the design of research and development stated by Borg and Gall. This design has 10 phases, but the researcher only applied 7 phases due to the phases which already modified, which are the potential and problems, data collection, design product, design validation, design revision, product testing, product revision. The Touch and Play 3D Images media in the Science Subject, The five senses Subject of 4th Grade students is part of the worthy to be used. Validity test held by the expert of the subject obtained the $87.5 \%$ percentage within the Valid Category. The test of validity by the learning expert gets the percentage value of $97.2 \%$ included in the valid category. The average result of the student's response shows the percentage of $97.61 \%$ is included in either category. In conclusion, the Touch and Play 3D Images based on Adobe Flash in the five senses subject of 4th Grade Elementary Students can be considered as Valid as the learning media
\end{abstract}

Kata kunci: adobe flash, elementary students, touch and play $3 d$ images, science,

\section{PENDAHULUAN}

Pembelajaran merupakan proses yang dilaksanakan oleh guru untuk mendampingi siswa dalam memperoleh dan memproses pengetahuan, keterampilan serta sikap (Iswahyudi \& Urbani, 2013). Proses belajar mengajar adalah upaya sistematis yang dilakukan oleh guru untuk mewujudkan pembelajaran berjalan secara efektif dan efisien yang dimulai dari perencanaan, pelaksanaan, dan evaluasi (Aqib, 2013; Setyaningrum \& Husamah, 2011).
Pembelajaran yang dilakukan oleh guru terdiri dari berbagai macam diantaranya adalah pembelajaran Ilmu Pengetahuan Alam (IPA) atau sains. IPA adalah salah satu mata pelajaran yang berkaitan dengan alam sekitar secara sistematis. IPA bukan sekedar kumpulan pengetahuan yang berupa fakta, konsep, atau prinsip saja, tetapi juga merupakan suatu proses penemuan sesuatu hal yang baru (Hermono, 2012; Husamah et al., 2016).

IPA termasuk mata pelajaran yang 
dikategorikan sulit untuk kalangan siswa sekolah dasar. IPA dianggap sulit oleh sebagian besar siswa karena banyak konsep yang cenderung memuat tentang ilmu hafalan baik teori maupun rumus (Vikagustanti, 2014). Observasi awal yang peneliti lakukan di SDN Sukorejo IV menunjukkan bahwa siswa kelas IV di sekolah tersebut belum mampu memahami Materi Panca Indera. Hal tersebut dikarenakan pembelajaran yang dilakukan oleh guru bersifat konvensional.

Materi panca indera cenderung sulit bagi siswa, sehingga guru membutuhkan media inovatif yang dapat digunakan dalam pembelajaran (Bustomi, 2013; Susiana, 2013; Wahyuningrih, 2017). Guru pun belum memanfaatkan media pembelajaran yang sesuai ataupun memadai. Padahal media memegang peran strategis dalam mendukung pencapaian kompetensi siswa pada proses pembelajaran (Hartati \& Safitri, 2017; Putri, 2016; Utariyanti et al., 2015).

Sehubungan dengan itu, diperlukan adanya pengembangan media pembelajaran sebagai alat bantu yang digunakan oleh guru agar siswa dapat memahami materi yang telah disampaikan dan pada akhirnya kompetensi siswa akan meningkat. Hal ini sejalan dengan Minarti et al (2012) yang menyatakan bahwa pembelajaran IPA yang masih berorientasi pada buku acuan dan media Slide presentasi dapat menimbulkan kejenuhan bagi siswa dalam suasana pembelajaran yang akhirnya menghambat pencapaian tujuan pembelajaram.

Media adalah alat yang dapat membantu proses belajar mengajar yang berfungsi memperjelas makna pesan yang disampaikan sehingga tujuan pengajaran dapat disampaikan dengan lebih baik dan lebih sempurna (Jupriyanto, 2011). Media Touch and Play 3D Images adalah sebuah media yang inovatif dan menarik dapat membangkitkan semangat belajar siswa kelas IV sekolah dasar, dimana media tersebut menggabungkan antara gambar 3D dan juga suara yang menunjang proses pembelajaran. Media ini juga menggunakan bahasa dan kalimat yang mudah dipahami oleh siswa sehingga mudah memahami materi yang dipelajari.

Pembuatan media Touch and Play $3 D$ Images menggunakan aplikasi Adobe flash. Menurut Iswahyudi dan Urbani (2013) flash adalah salah satu program pembuatan animasi yang sangat handal. Kehandalan flash dibandingkan dengan program yang lain adalah dalam hal ukuran file dari hasil animasinya yang kecil. Flash juga menjadi salah satu alternatif dalam pembuatan animasi bergerak yang kemudian kita kenal dengan istilah kartun.

Hasil penelitian Mubarok (2016) tentang media pembelajaran yang menunjang kompetensi sistem bahan bakar konvensional siswa kelas XI TKR dengan menggunakan aplikasi Adobe flash menyimpulkan bahwa media yang telah dikembangkan tersebut valid digunakan sebagai media pembelajaran. Berdasarkan hal tersebut maka pengembangan media pembelajaran Touch and Play 3D Images berbasis Adobe flash perlu dan logis untuk dilakukan. Tujuan penelitian pengembangan ini adalah menghasilkan suatu produk yang berupa media pembelajaran Touch and Play 3D Images berbasis Adobe flash materi penca indera kelas IV sekolah dasar.

\section{METODE}

\section{Jenis Penelitian}

Penelitian ini menggunakan metode Research and Development yang merujuk serangkaian tahapan model Borg and Gall. Penelitian pengembangan ini memodifikasi 10 langkah model Borg and Gall menjadi 7 langkah merujuk pada Hasyim (2016) dikarenakan pada langkah ke 8, 9, dan 10 yaitu uji lapang skala luas, revisi, dan desiminasi dan implementasi merupakan penelitian lanjutan yang membutuhkan 
waktu yang lama, tenaga yang cukup besar, serta biaya yang besar. Dalam artikel ini pun hanya akan menyajikan data hasil validasi ahli dan gambaran media yang telah dikembangkan.

\section{Waktu, Tempat dan Subjek Penelitian}

Penelitian ini dilaksanakan di SDN Sukorejo IV pada bulan Juni-Juli 2017. Subjek penelitian pengembangan adalah siswa kelas IV SDN Sukorejo IV yang berjumlah 15 siswa.

\section{Teknik Analisis Data}

Teknik analisis data yang digunakan dalam penelitian dan pengembangan ini antara lain:

\section{Analisis Data Kevalidan media}

Data kevalidan media Touch and Play 3D Images didapatkan dari angket validasi para ahli. Untuk mengetahui nilai akhir dari angket validasi yang di isi oleh para ahli, maka dapat dilakukan dengan menghitung nilai rata-rata setiap validator dengan menghitung jumlah nilai semua aspek dibagi banyaknya pertanyaan. Data angket validasi para ahli menggunakan rating scale dalam penilaiannya merujuk Sugiyono (2015), seperti pada Tabel 1.

Tabel 1. Penilaian Rating scale

\begin{tabular}{ccc}
\hline No & Keterangan & Skor \\
\hline 1. & Sangat baik & 4 \\
2. & Baik & 3 \\
3. & Cukup baik & 2 \\
4. & Tidak baik & 1 \\
\hline
\end{tabular}

(Sumber: Sugiyono, 2015)

Perhitungan presentase dari data yang telah diperoleh diolah dengan menggunakan rumus berikut:

$$
\mathrm{P}=\frac{\sum x}{\sum i} \times 100 \%
$$

Keterangan:

P :Persentase

$\sum_{\mathrm{x}}$ :Jumlah keseluruhan jawaban
responden dalam seluruh item $\sum_{\mathrm{i}}$ :Jumlah keseluruhan skor ideal dalam per item

100\%: Konstanta

Setelah nilai validasi diketahui maka peneliti dapat menyimpulkan apakah produk yang dikembangkan valid atau tidak dengan cara melihat tabel tingkat kevalidan, sebagaimana pada Tabel 2 .

Tabel 2. Tingkat Kevalidan

\begin{tabular}{ll}
\hline \multicolumn{1}{c}{ Nilai (\%) } & \multicolumn{1}{c}{ Kategori } \\
\hline $75<\mathrm{P} \leq 100$ & Sangat Valid \\
$50<\mathrm{P} \leq 75$ & Valid \\
$25<\mathrm{P} \leq 50$ & Kurang Valid \\
$\mathrm{P} \leq 25$ & Tidak Valid \\
\hline
\end{tabular}

(Sumber: Arikunto, 2008)

2. Analisis Data Angket Respon Siswa

Data yang diperoleh dari hasil angket respon siswa kemudian dianalisis menggunakan data kuantitatif. Jawaban angket respon siswa menggunakan angket skala Guttman yang menggunakan dua kategori yang dibuat dalam bentuk pilihan, yaitu "Ya atau Tidak", seperti pada Tabel 3.

Tabel 3. Kategori Penilaian Skala Guttman

\begin{tabular}{ll}
\hline \multicolumn{1}{c}{ Skor } & \multicolumn{1}{c}{ Keterangan } \\
\hline Skor 1 & Ya \\
Skor 0 & Tidak \\
\hline
\end{tabular}

(Sumber: Sugiyono, 2015)

Uji angket respon siswa ini dapat dilakukan dengan menggunakan rumus berikut:

$$
\mathrm{P}=\frac{\sum x}{\sum i \mathrm{i}} \times 100 \%
$$

Keterangan:

P :Presentase

$\sum_{\mathrm{x}}$ :Jumlah keseluruhan jawaban responden dalam seluruh item

$\sum_{\mathrm{i}} \quad$ :Jumlah keseluruhan skor ideal dalam per item

100\%: Konstanta

Setelah hasil respon siswa diketahui, maka hasil respon siswa dapat dicocokkan 
dengan interval tingkat hasil nilai respon siswa yang ada, sebagaimana pada Tabel 4.

Tabel 4. Interval Tingkat Hasil Nilai Respon Siswa

\begin{tabular}{cll}
\hline No & $\begin{array}{c}\text { Persentase Hasil } \\
\text { Nilai Respon } \\
\text { Siswa }\end{array}$ & \multicolumn{1}{c}{ Kriteria } \\
\hline 1. & $85-100 \%$ & Sangat Baik \\
2. & $70-84 \%$ & Baik \\
3. & $55-69 \%$ & Cukup \\
4. & $40-54 \%$ & Kurang \\
5. & $0-39 \%$ & Sangat Kurang \\
\hline
\end{tabular}

(Sumber: Utomo, 2010)

\section{HASIL DAN PEMBAHASAN}

Hasil akhir pengembangan media Touch and Play 3D Images yang telah direvisiberdasarkanmasukan paravalidator yaitu Slide awal yang berupa cover media yang berisi judul materi pembelajaran dibagian tengah atas. Pada bagian samping kiri Slide terdapat tombol penyusun untuk mengetahui identitas peneliti. Bagian kiri bawah terdapat tombol suara tentang pengertian panca indera dan bagian samping kanan Slide tombol "masuk" yang apabila di sentuh akan menuju Slide utama. Terdapat gambar kepala manusia diantara tombol "penyusun" dan tombol "masuk", sebagaimana ditunjukkan pada Gambar 1.

Slide utama terdiri dari macammacam menu panca indera yang apabila di klik salah satunya akan muncul deskripsi dan juga gambar atau video terkait. Bagian awal Slide utama juga berisi SK, $\mathrm{KD}$, dan indicator, sebagaimana disajikan pada Gambar 2. Tampilan menggunakan font Comic sands MS, Segoe script, dan juga Times new roman dan font size 14 pt. Sementara itu, pada bagian akhir Slide terdapat informasi tentang profil pengembang (penulis), seperti dtunjukkan pada Gambar 3.

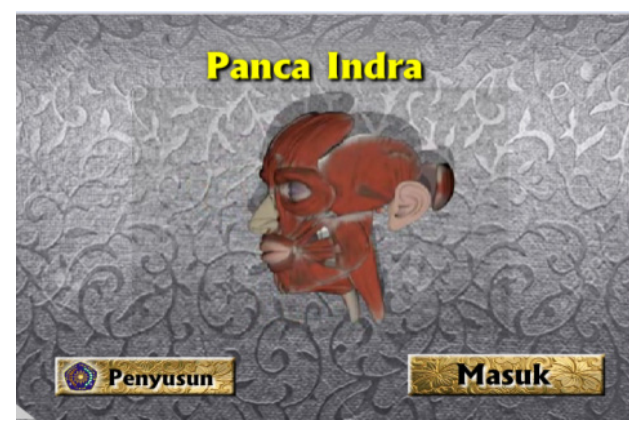

Gambar 1. tampilan Slide awal media Touch and Play 3D images

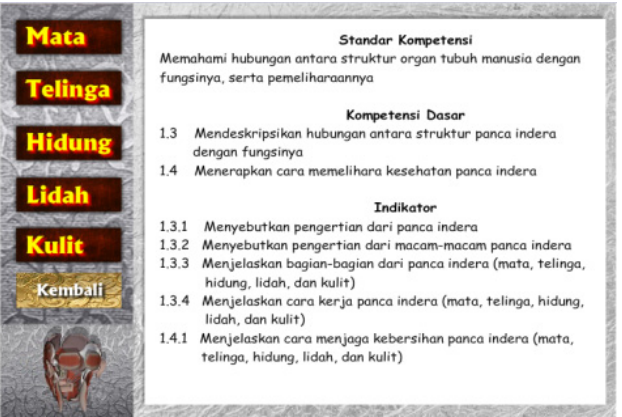

Gambar 2. Tampilan Slide utama media Touch and Play 3D images.

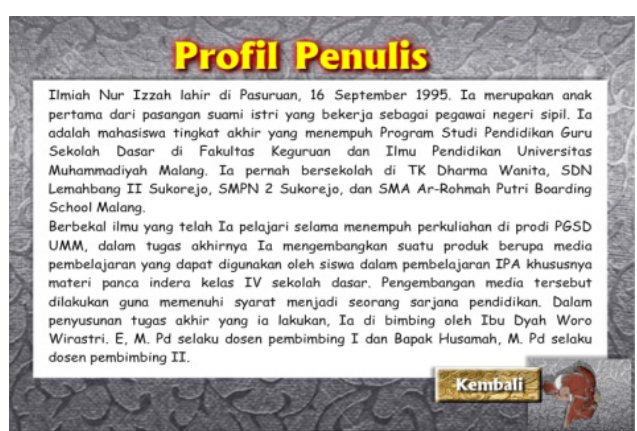

Gambar 3. Tampilan Slide setelah mengklik penyusun

Hasil validasi media Touch and Play $3 D$ Images oleh para validator dipaparkan pada Tabel 5.

Tabel 5. Hasil Validasi Para Ahli

\begin{tabular}{ccl}
\hline $\begin{array}{c}\text { Sebelum } \\
\text { Revisi (\%) }\end{array}$ & $\begin{array}{c}\text { Sesudah } \\
\text { Revisi (\%) }\end{array}$ & \multicolumn{1}{c}{ Validator } \\
\hline 65,6 & 87,5 & Ahli Media \\
63,9 & 83,3 & Ahli Materi \\
97,2 & 97,2 & Ahli \\
& & Pembelajaran \\
\hline Rata-Rata & 89,3 & \\
Validator & & \\
\hline
\end{tabular}


Hasil respon siswa terhadap media Touch and Play 3D Images yang dikembangkan dipaparkan pada Tabel 6

Tabel 6. Hasil Respon Siswa

\begin{tabular}{cc}
\hline Siswa & Persentase (\%) \\
\hline S1 & 100 \\
S2 & 93,3 \\
S3 & 93,3 \\
S4 & 100 \\
S5 & 100 \\
S6 & 100 \\
S7 & 93,3 \\
S8 & 100 \\
S9 & 100 \\
S10 & 100 \\
S11 & 93,3 \\
S12 & 93,3 \\
S13 & 100 \\
S14 & 100 \\
\hline Rata-Rata Total & 97,6 \\
\hline
\end{tabular}

Berdasarkan hasil validasi yang dilakukan oleh para ahli sebagaimana pada Tabel 5 dan juga hasil respon siswa pada Tabel 6 dapat disimpulkan bahwa media Touch and Play 3D Images dinyatakan valid dan layak dijadikan sebagai media pembelajaran materi panca indera kelas IV sekolah dasar.

Media Touch and Play 3D Images dapat dikatakan sangat valid untuk proses pembelajaran karena mendapat persentase nilai dari para ahli validator sebesar 83,3\% untuk ahli materi, 87,5\% untuk ahli media, dan 97,2\% untuk ahli pembelajaran. Jika merujuk pada Arikunto (2008) maka persentase hasil validasi dari para validator lebih dari $75 \%$ maka media pembelajaran yang dikembangkan sangat valid digunakan dalam pembelajaran. Hasil respon siswa terhadap media Touch and Play $3 D$ Images pun dapat dikatakan termasuk dalam kategori sangat baik dengan perolehan persentase rata-rata sebesar 97,6\%. Hasil tersebut didapat karena pembuatan media disesuaikan dengan tumbuh kembang siswa, dimana siswa sekolah dasar cenderung menyukai untuk menemukan hal yang baru dan konkrit (tidak abstrak). Menurut Winarni (2012) siswa SD usianya sekitar 6 sampai dengan 12 tahun masih berada pada operasional konkret. Media yang didesain secara baik untuk membuat materi menjadi konkrit menjadi jembatan yang sangat membantu pemahaman siswa terhadap sesuatu yang abstrak.

Media Touch and Play 3D Images ini didesain sedemikian sehingga dapat membantu siswa untuk memahami materi panca indera secara keseluruhan dan tidak menyebabkan kejenuhan. Selain itu agar siswa dapat belajar secara mandiri. Hal ini sesuai dengan fungsi dari suatu media pembelajaran dalam proses pembelajaran, yaitu (a) media pembelajaran dapat memperjelas penyajian pesan dan informasi, (b) media pembelajaran dapat meningkatkan dan mengarahkan perhatian anak sehingga menimbulkan motivasi, (c) media pembelajaran dapat mengatasi keterbatasan indera, ruang dan waktu, (d) media pembelajaran dapat memberikan kesamaan pengalaman kepada siswa tentang peristiwa dilingkungan mereka (Novaliendry, 2013). Pembelajaran yang secara serius dirancang oleh guru, baik dalam penyiapan mendia atapun dalam strategi cenderung akan meningkatkan motivasi para siswa (Husamah \& Pantiwati, 2014).

Hasil penelitian ini sejalan dan mendukung beberapa penelitian sebelumnya, terutama dalam hal integrasi teknologi flash dalam pembelajaran IPA. Penelitian Prasetyaningsih (2015) menunjukkan bahwa pembelajaran menggunakan media pembelajaran IPA berbasis Adobe flash CS5 terbukti lebih efektif terhadap prestasi siswa kelas V SD Muhammadiyah Ambarketawang 3.

Penelitian Umiyati \& Zuhdi (2014) juga menunjukkan adanya peningkatan persentase aktivitas guru, siswa dan hasil 
belajar siswa dengan memanfaatkan media flash card dapat meningkatkan hasil belajar IPA pada tema lingkungan.

\section{SIMPULAN}

Berdasarkan penelitian dan pengembangan yang telah dilakukan dapat disimpulkan bahwa pengembangan dengan menggunakan metode Research and Development yang merupakan serangkaian tahapan dari Borg and Gall yang sudah dimodifikasi dari 10 langkah menjadi 7 langkah dapat menghasilkan suatu produk berupa media Touch and Play 3D Images yang dinyatakan valid dan layak digunakan sebagai media pembelajaran materi panca indera kelas IV berdasarkan hasil validasi para ahli dan juga hasil respon siswa terhadap media yang telah dikembangkan.

\section{DAFTAR PUSTAKA}

Aqib, Z. (2013). Model-model, media dan strategi pembelajaran kontekstual (inovatif). Bandung: Yrama Widya

Arikunto, S. (2008). Prosedur penelitian: suatu pendekatan praktik. Jakarta: PT Rineka Cipta.

Bustomi, A. Y. (2013). Aplikasi Pembelajaran Panca Indra Pada Manusia Berbasis Android (Studi Kasus: SDN Pruwatan 03). Jurnal Telematika, 6(1), 1-14.

Hartati, T. A. W. \& Safitri, D. (2017). The Respon of IKIP BUDI UTOMO Students toward the Instructional Book of Cell Biology Subject Aided by Interactive Multimedia. Jurnal Pendidikan Biologi Indonesia, 3(2), 166-173.

Hasyim, A. (2016). Metode penelitian dan pengembangan di Sekolah. Yogyakarta: Media Akademi.

Hermono, F., \& Hakim, F. N. (2012). Perancangan media pembelajaran berbasis multimedia (studi kasus mata pelajaran IPA bahasan gerak benda kelas III SDN Dempelrejo). Journal Speed-Sentra Penelitian Engineering dan Edukasi, 4(1), 4249.

Husamah \& Pantiwati, Y. (2014). Cooperative learning STAD-PjBL: Motivation, thinking skills, and learning outcomes in Biology Students. International Journal of Education Learning \& Development (IJELD), 2(1), 77-94.

Husamah, Pantiwati, Y., Restian, A. \& Sumarsono, P. (2016). Belajar dan Pembelajaran. Malang: UMM Press.

Iswahyudi., \& Urbani, Y. H. (2013) Pembuatan media pembelajaran Ilmu Pengetahuan Alam kelas 5 Sekolah Dasar Negeri Dagen 1 Jaten. Seminar Riset Unggulan Nasional Informatika dan Komputer FTI UNSA, 2(1), 61-67

Jupriyanto., \& Ganis, E. I. (2011). Pengenalanadattradisionalindonesia berbasis multimedia pada Madrasah Ibtidaiyah Muhammadiyah (Mim) Ngadirejan. Journal Speed - Sentra Penelitian Engineering dan Edukasi, 3(4), 40-44.

Minarti, I. B., Susilowati, S. M. E., \& Indriyanti D. R. (2012). Perangkat pembelajaran IPA terpadu bervisi sets berbasis edutainment pada tema pencernaan. Journal of Innovative Science Education, 1(2), 105-111.

Novaliendry, D. (2013). Aplikasi game geografi berbasis multimedia interaktif (studi kasus siswa kelas IX SMPN 1 RAO). Jurnal Teknologi Informasi dan Pendidikan, 6(2), 106-118.

Prasetyaningrih, I. (2015). Pengembangan Media Pembelajaran IPA Berbasis Adobe flash CS5 Untuk Siswa Kelas V Sekolah Dasar. Online: repository. upy. ac.id/312/1/Jurnal\%20Indri\% 20Prasetyaningsih.pdf.

Putri, L. O. L. (2016). Card of Identification 
Phylum as an Innovative Media to Study Animal Classifications. Jurnal Pendidikan Biologi Indonesia, 2(1), 31-38.

Setyaningrum, Y. \& Husamah. 2011 Optimalisasi Penerapan Pendidikan Karakter di Sekolah Menengah Berbasis Keterampilan Proses: Sebuah Perspektif Guru IPABiologi. Jurnal Penelitian dan Pemikiran Pendidikan, 1(1), 69-81.

Sugiyono. (2015). Metode penelitian pendidikan pendekatan kuantitatif, kualitatif, dan $R$ \& D. Bandung: Alfabeta.

Susiana, S. (2013). Penggunaan Media Gambar dalam Pembelajaran IPA Untuk Meningkatkan Hasil Belajar Kelas IV Sekolah Dasar. Artikel Penelitian. Pontianak: Universitas Tanjung Pura.

Umiyati, T. \& Zuhdi, U. (2014). Pemanfaatan Media Flash Card Untuk Meningkatkan Hasil Belajar IPA Tema Lingkungan Pada Siswa di Sekolah Dasar. JPGSD, 2(3), 1-7.

Utariyanti, I. F. Z., Wahyuni, S. \& Zaenab, S. (2015). Pengembangan Media Pembelajaran Berbasis Komik Dalam Materi Sistem Pernapasan Pada Siswa Kelas VIII MTs Muhammadiyah 1 Malang. Jurnal Pendidikan Biologi Indonesia, 1(3), 343-355.
Utomo, D. P. (2010). Pengembangan perangkat pembelajaran berbasis masalah pada pembelajaran pecahan kelas IV SD. Sekolah Dasar, 19(1). Online: http://journal.um.ac.id/ index. php/jurnal-sekolah-dasar/ article/view /3631/0.

Vikagustanti, D. A., Sudarmin, \& Pamelasari, S. D. (2014). Pengembangan media pembelajaran monopoli IPA tema organisasi kehidupan sebagai sumber belajar untuk siswa SMP. Unnes Science Education Journal, 3(2), 468-475.

Wahyuningsih, T. (2017). Pengembangan Media Kartu Domino Modifikasi pada Pembelajaran IPA Materi Indra Pendengar dan Peraba untuk Siswa Kelas IV SD Kanisius Kenteng. Skripsi tidak diterbitkan. Yogyakarta: FKIP Univ. Sanata Dharma.

Winarni, E. S. (2012). Membangun Karakter Siswa Sekolah Dasar (SD) Melalui Pembelajaran Matematika Dengan Menggunakan Media Benda Konkret. Prosiding Seminar Nasional Matematika dan Pendidikan Matematika, Jurusan Pendidikan Matematika FMIPA UNY. 